\title{
Penerapan Model Cooperative Script dalam Pembelajaran PKn untuk Meningkatkan Hasil Belajar Siswa Pada Konsep Bangga Sebagai Anak Indonesia
}

\author{
Ulwan Syafrudin, Darmawan, Ita Rustiati Ridwan \\ Universitas Negeri Jakarta, Universitas Pendidikan Indonesia \\ ulwansyafrudin23@gmail.com, darwaman@gmail.com, ita.rustiati@gmail.com
}

\begin{abstract}
In PKn Learning in the concept of being proud as an Indonesian child there are many third grade students of SDIT Harapan Ummat Jakarta who get a less than optimal score. From the results of observations, the teacher uses a less varied learning method so that it does not support student activity and is less focused on the subject matter. Therefore, to improve the learning process, using the Cooperative Script model is expected to help students improve and improve their learning outcomes. The specific purpose of this study is to identify the steps and improve student learning outcomes through the Cooperative Script model in PKn learning. The type of this research used was Classroom Action Research using the Kemis and Teggart models conducted at SDIT Harapan Ummat with 35 students. The results of this study experienced a lot of improvement in activities and learning outcomes. from the results of observing the activities of students in the first cycle that is $57 \%$, with enough categories and experiencing an increase in the second cycle to $84 \%$, with the category Very good. While the average value of student learning outcomes in pre-cycle 36, cycle I 75.2, and cycle II increased to 92. From the results obtained concluded that learning using Cooperative Script learning models in Civics learning on the concept of pride has succeeded with increasing learning outcomes students. Recommendations to teachers as a reference for preparing lesson plans in improving professional skills in teaching Civics material for students in their classrooms, as well as broadening teacher insights and knowledge in applying Cooperative Script learning models.
\end{abstract}

Keywords: Cooperative Script, Learning Outcomes, Civics Learning

Abstrak :Pada Pembelajaran PKn dalam konsep bangga sebagai anak Indonesia banyak sekali siswa kelas III SDIT Harapan Ummat Jakarta yang mendapatkan nilai yang kurang maksimal. Dari hasil observasi, guru menggunakan metode pembelajaran yang kurang variatif sehingga

AR-RIAYAH : Jurnal Pendidikan Dasar vol. 2, no. 2, 2018

STAIN Curup - Bengkulu| pISSN2580-362X;e ISSN2580-3611

http://journal.staincurup.ac.id/index.php/JPD 
kurang menunjang keaktifan siswa dan kurang fokus terhadap materi pelajaran. Oleh sebab itu, untuk memperbaiki proses pembelajaran, dengan menggunakan model Cooperative Script diharapkan membantu siswa dalam memperbaiki dan meningkatkan hasil belajarnya. Adapun tujuan khusus penelitian ini adalah untuk mengindentifikasi langkahlangkah dan meningkatkan hasil belajar siswa melalui model Cooperative Scriptpada pembelajaran PKn. Jenis penelitian ini yang digunakan adalah Penelitian Tindakan Kelas dengan menggunakan model Kemis dan Teggart yang dilakukan di SDIT Harapan Ummat dengan jumlah siswa 35.Hasil penelitian ini banyak mengalami peningkatan pada aktivitas dan hasil belajar.dari hasil obeservasi aktivitas siswa pada siklus I yaitu 57\%, dengan kategori cukup dan mengalami peningkatan pada siklus II menjadi 84\%, dengan kategori Amat baik. Sedangkan nilai rata-rata hasil belajar siswa pada pra siklus 36, siklus I 75,2, dan siklus II meningkat menjadi 92. Dari hasil yang didapatkandisimpulkan bahwa pembelajaran menggunakan model pembelajaran Cooperative Scriptpada pembelajaran PKn pada konsep bangga telah berhasil dengan meningkatnya hasil belajar siswa .Rekomendasi kepada guru sebagai acuan untuk menyusun RPP dalam meningkatkan kemampuan profesional dalam mengajarkan materi PKn bagi siswa di kelasnya, serta memperluas wawasan dan pengetahuan guru dalam menerapkan model pembelajaran Cooperative Script.

Kata Kunci :Cooperative Script, Hasil Belajar, Pembelajaran PKn

\section{PENDAHULUAN}

Pendidikan kewarganegaraan merupakan salah satu mata pelajaran yang digunakan untuk mengembankan moral banggsa dan budaya Indonesia agar tercipta manusia yang berkarakter. Pembelajaran PKn di SD Dimaksudkan untuk penanaman sikap dan tatakrama yang dilakukan selama enam tahun dalam membentuk karakter bangsa yang sesuai dengan pancasila dan norma yang berlaku dimasyarakat. ${ }^{2}$

Berkenaan hal tersebut Pendidikan kewarganegaraan (PKn) memiliki kontribusi yang sangat besar terhadap perkembangan siswa khususnya di zaman modern saat ini.Melihat dari berbagai pengertian pembelajaran PKn yang telah dipaparkan diatas dapat dimpulkan bahwa Pendidikan Kewarganegaraan adalah

\footnotetext{
${ }^{1}$ Ahmad Susanto, Teori Belajar dan Pembelajaran (Yogyakarta : Prenada Media Group, 2010), 225.

IIbid., 227.
} 
pendidikan yang mengenai tentang konsep negara dan cara bagaimana mempersiapkan warga negara untuk selalau berpikir kritis dalam setiap keadaan yang menurut kita tidak sesuai dengan norma dan nilai yang ada dan memiliki tujuan untuk menjadikan warga negara yang baik dan sadar akan hak serta kewajibannya.

Berdasarkan hasil studi pendahuluan yang dilakukan melalui observasi dan wawancara terhadap guru kelas III SD N Kamalaka Kecamatan Taktakan Kota Serang, diperoleh informasi bahwa terdapat permasalahan terkait kurang maksimalnya hasil belajar siswa kelas III pada pembelajaran PKn materi Bangga Sebagai Anak Indonesia dikarenakan :1. penggunaan metode pembelajaran yang kurang variatif sehingga kurang dapat menunjang keaktifan siswa dan kurang fokus terhadap materi pelajaran. 2. rata-rata siswa hanya memperhatikan guru pada 15 menit pertama proses pembelajaran, selebihnya siswa mengobrol dengan teman sekelas.3.minat baca siswa yang kurang dalam membaca buku pelajaran PKN, ini berakibat pada minimnya pengetahuan siswa terkait konsep Bangga sebagai anak Indonesia.4.siswa mengangap remeh mata pelajaran PKn, karena materinya yang seringkali berhubungan dengan kegiatan sehari-hari, hal ini menyebabkan siswa kurang kreatif dan bersemangat dalam pembelajaran.

Permasalahan tersebut dibuktikan dengan data lapangan hanya 3 orang yang mendapat nilai 80,4 orang mendapatkan 70 dan 28 orang mendapatkan nilai dibawah 70, dari total jumlah siswa 35. Sedangkan nilai KKM yang telah ditentukan pada pembelajaran PKn yakni 63.Data ini membuktikan siswa yang mencapai KKM hanya 7 orang dan 31 orang yang tidak mencapai KKM.

Dalam memperbaiki proses pembelajaran, dengan menggunakan model Cooperative Script diharapkan dapat menjadi solusi untuk guru dalam meningkatkan aktivitas dan hasil belajar siswa.

Latar belakang masalah diatas perlu diidentifikasi permasalahan yang ada yaitu. Guru menggunakan metode pembelajaran yang kurang variatif sehingga kurang dapat menunjang keaktifan siswa dan kurang fokus terhadap materi pelajaran. Rata-rata siswa hanya memperhatikan guru pada 15 menit pertama proses pembelajaran, selebihnya siswa mengobrol dengan teman sekelas. Banyak siswa dikelas yang tidak naik kelas dan belum bisa membaca sehingga guru sulit dalam menyampaikan materi.minat baca siswa yang kurang dalam membaca buku pelajaran PKn, hal ini berakibat pada minimnya pengetahuan siswa terkait konsep Bangga sebagai anak Indonesia. Siswa menganggap remeh mata pelajaran $\mathrm{PKn}$, karena materinya yang seringkali 
berhubungan dengan kegiatan sehari-hari, hal ini menyebabkan siswa kurang kreatif dan bersemangat dalam pembelajaran.

Permasalahan utama dalam penelitian ini adalah bagaimana penerapan model cooperative script yang tepat dalam pembelajaran PKn untuk meningkatkan hasil belajar siswa.Penelitian ini bertujuan untuk meningkatkan kualitas pembelajaran PKN di sekolah dasar melalui penerapan model cooperative script dalam pembelajaran PKn untuk meningkatkan hasil belajar siswa pada konsep bangga sebagai anak Indonesia.

Lambiotte, dkk menyatakan bahwa cooperative scriptadalah dimana siswa dalam pembelajaran diminta untuk berpasangan dalam menghapl materi yang telah diringkas. ${ }^{3}$

\section{METODE PENELITIAN}

Metode dalam penelitian ini adalah Penelitian Tindakan Kelas (PTK). Menurut arikunt penelitian tindakan kelas adalah upaya untuk memperbaiki pembelajaran yang sengaja dilakukan dikelas. Dengan cara ini peneliti sengaja untuk membangkitkan semangat sehingga terjadi pembelajaran yang berkualitas pada mata pelajaran PKn dalam materi bangga sebagai anak Indonesia dikelas III SDIT Harapan Ummat Kecamatan Matraman Jakarta Timur. Adapun siklusnya bukan sekali tetapi berkali-kali sampai kita rasa cukup untuk mengakhiri penelitian atau tujuan sudah tercapai. Adapun hal penelitian tersebut yang akan digunakan adalah model Kemmis dan Taggart. Menggunakan model ini karena mudah dipahami dan mudah diguanakan bahkan sering digunakan peneliti-peneliti lainnya.

Subjek penelitian tindakan kelas ini adalah seluruh siswa kelas III SDIT Harapan Ummat dengan jumlah total siswa keseluruhan 35 siswa yang terdiri 15 Laki-laki dan 20 perempuan.Penelitian Tindakan Kelas ini di dilaksanakan di SDIT Harapan Ummat Kecamatan Matraman Jakarta Timur.

Instrument dalam penelitian ini yang digunakan berupa Observasi dan Tes. Tes yang digunakan yaitu dari pemberian pretest dan posttes untuk mengetahui hasil belajar siswa sebelum dan sesudah dilakukan tes.observasi untuk mengetahui aktivitas dan percakapan siswa pada pembelajaran PKn. 2013), 213.

${ }^{3}$ M. Huda, Model-Model Pengajaran dan Pembelajaran (Yogyakarta : Pustaka Pelajar, 
Observasi ini dilakukan dengan 2 cara yakni dengan observasi non-sistematis dan observasi sistematis. Pada penelitian ini yang di gunakan observasi sistematis yaitu dalam pengamatannya berpedoman pada instrument yang tlah dibuat. Observasi ini dilakukan untuk bertujuan melihat keaktifan siswa dalam pembelajaran Pkn dengan menggunakan model pembelajaran cooperative script.Dengam menggunakan observasi ini karena lebih mudah dilakukan dan dipahami jadi kita bisa menilai keaktivifan siswa dengan melihat pedoman tidak menilai diluar pedoman. Kemudian Tes hasil belajar ini dalam penelitian dimaksudkan untuk mengetahui sejauh mana hasil belajar siswa pada pembelajaran Pkn pada konsep Bangga sebagai anak Indonesia jadi diharpakan dengan mengetahui dan mengukur kemampuan siswa. Pada kelas III SD Soal yang diberikan pada tes ini terdiri dari 10 soal essay yang memiliki bobot yang berbeda-beda dari mudah, sedang sampai sukar. Kemudian teknik analisis data yang digunakan yaitu teknik analisis data model Miles and Huberman. Menurut sugiyono (2014)Aktivitas analisis kualititatif berlangsung secara terus menerus sampai dirasa cukup dan jenuh.Jadi dengan demikain analisis data kualitatif adalah penelitian secara terus-menerus sampai kita merasa sudah selesai untuk mengakhiri penelitian.denganmenggunakan model analisis ini dalam mengelola datanya tidak susah karena tidak perlu dicantumkan nilai sekian dapat tersebut dari mana.

Keberhasilan dalam penerapan model pembelajaran cooperative script dalam pembelajaran PKn untuk meningkatkan hasil belajar siswa pada konsep bangga sebagai anak Indonesia adalah yang pertama terjadinya peningkatan aktivitas belajar siswa dengan kategori aktif dengan nilai diatas 8.Kedua adanya peningkatan dari tiap-tiap siklusnya.Yang ketiga Ketuntusan belajar siswa dengan presentase mencapai $80 \%$ dari jumlah siswa keseluruhan dengan KKM 63.

\section{HASIL PENELITIAN}

Berdasarkan hasil penelitian mulai dari proses pelaksanaan, hasil dan pembahasaan adalah sebagai berikut :

\section{Pelaksanaan}

Pra Siklus

a. Observasi

Observasi awal ini dilakukan untuk melihat cara mengajar guru didalam kelas pada pembelajaran PKn pada konsep bangga sebagai anak Indonesia. Pada 
kegiatan awal guru melakukan apersepsi dengan mengaitkan materi setelah itu guru menulis materi dipapan tulis dan guru menjelaskan menggunakan metode yang kurang variatif sehingga siswa kurang aktif dan sering berbicara dengan teman sebangku.Hasil belajar siswa pada pra siklus yaitu dengan presentase $20 \%$ dan nilai rata-ratanya yaitu 36 sedangkan batas kelulusan yang sudah ditentukan sesuai KKM adalah 63. Hal ini menunjukan bahwa betapa rendahnya hasil belajar siswa dalam pembelajaran PKn dan perlu adanya perbaikan.

b. Refleksi

Jumlah siswa yang belum tuntas dalam pembelajaran PKn terdapat 28 orang dengan presenatse $20 \%$. Hal ini menunjukan bahwa hampir semua siswa belum menguasai materi Bangga Sebagai Anak Indonesia.Banyak sekali permasalahan yang didalam kelas baik itu dari siswanya dan gurunya.

Untuk mencapai tujuan pembelajaran yang diinginkan peneliti dan guru berupaya mencari solusi untuk memperbaiki hasil belajar siswa dengan menggunakan model pembelajaran cooperative script pada pembelajaran PKn. Dengan menggunakan model ini siswa dituntut untuk aktif dengan bekerja sama dengan teman sebangku untuk menghapal ringkasan materi dalam memahami suatu masalah yang terjadi.Maka peneliti melakukan tindakan perbaikan pada siklus selanjutnya dengan menggunakan model cooperative script pada pembelajaran PKn pada konsep bangga sebagai anak Indonesia.

Siklus 1

a. Perencanaan

Peneliti merancang dengan mebuat skenario pembelajaran mengenai konsep bangga sebagai anak Indonesia dengan menggunakan model pembelajaran cooperative script. pada awal pembelajaran peneliti akan memberikan topik mengenai materi yang akan dibahas yaitu bangga sebagai anak Indonesia. Setelah pengenalan topik guru sedikit menjelaskan mengenai bangga sebagai anak Indonesia dan menjelaskan bagaimana cara pembelajaran kali ini agar siswa tergambar mengenai pada materi ini. Setelah pengenalan topik guru mengatur siswa secara berpasangan. Setelah berpasangan guru memyebarkan materi ketiap masing-masing siswa dan meminta untuk dibaca dan membuat rangkuman. Selain itu guru menetapkan siapa yang menjadi pembicara dan pendengar. Dan guru membuat soal evaluasi yang akan diberikan diakhir proses pembelajaran. Setelah semuanya membacakan ringkasan materi, maka siswa diminta untuk berdiskusi tentang materi yang telah dihapal, kemudian setelah selesai 
memberikan soal evalusi di akhir proses kegiatan pembelajaran. Guru bertanya apa saja atau yang masih belum dimengerti mengenai materi yang telah didapatkan. Diakhir pembelajaran guru bersama siswa membuat kesimpulan mengenai materi yang telah dipelajari dilanjutkandengan menutup pembelajaran. b. Tindakan

Guru memulai mengajar sesuai apa yang dibuat di RPP yaitu sebelum pelajaran dimulai, guru mengajak siswa untuk berdoa bersama-sama, kemudian guru mengenalkan topik yang akan dibahas mengenai konsep bangga sebagai anak Indonesia, mengatur siswa untuk berpasangan,guru menyebarkan wacana kepada masing-masing siswa untuk dibaca dan membuat rangkuman setelah itu guru memutuskan siapa yang pertama menjadi pembicara dan siapa yang menjadi pendengar setelah itu memberikan soal evaluasi individu yang dilakukan untuk mengetahui tingkat keberhasilan hasil belajar siswa. Guru menanyakan kepada siswa mungkin ada yang belum dipahami dan guru mencoba menjawab. Guru bersama siswa membuat kesimpulan

c. Observasi

Dalam kegiatan observasi ini dilakukan saat proses pembelajaran berlangsung. presentase yang diperoleh mencapai 58\% dari presentase tersebut menunjukkan aktivitas belajar siswa yang masih kurang. Dan hasil belajar siswa presentase 68,6\% dari KKM yang ditentukan sekolah yaitu 63. Dari hasil tersebut menunjukkan bahwa kemampuan siswa dalam menguasai materi sudah baik tetapi belum memenuhi target yakni $80 \%$. oleh karena itu hasil yang didapatkan pada siklus I ini masih belum mencapai target dan untuk memperbaikinya peneliti merasa memerlukan siklus selanjutnya banyak yang harus diperbaiki terutama pada kesiapan siswa dalam menerapakan metode ini.

d. Refleksi

Hasil siklus I dalam pembelajaran PKn tentang materi bangga sebagai anak Indonesia dalam proses pembelajarannya sudah cukup baik tetapi masih ada kendala dan kekurangannya. Kendala yang ditemukan adalah siswa saat bekerja kelompok dalam menghapal materi masih sedikit melihat ringkasan materi sehingga data yang didapat masih belum meyakinkan. Hasil belajar siswa pada siklus I diperoleh nilai rata-rata 74 dan jumlah siswa yang belum tuntas yaitu 11 orang dengan presentase 31,4\%. Untuk itu peneliti dan guru ingin berupaya mencari solusi untuk meningkatkan lagi hasil belajar siswa dengan memperbaiki rencana pelaksanaan pembelajaran (RPP) pada siklus II, 
membimbing siswa agar lebih aktif lagi dan tercapai apa yang diharapkan. Maka dari itu peneliti merasa belum berhasil pada siklus I dan berupaya memperbaiki dengan melaksanakan tindakan pada siklus II.

\section{Siklus 2}

\section{a. Perencanaan}

Pada siklus II ini peneliti kembali membuat RPP dengan berdasarkan temuan pada penelitian sebelumnya. Adapun perencanaan yang akan peneliti lakukan adalah memperbaiki RPP mengenai konsep bangga sebagai anak Indonesia dengan menggunakan model cooperative script.Pada awal pembelajaran peneliti akan memberikan topik mengenai materi yang akan dibahas tentang bangga sebagai anak Indonesia. Setelah pengenalan topik guru memberi penjelasan mengenai bangga sebagai anak Indonesia dan menjelaskan bagaimana cara pembelajaran kali ini supaya siswa tergambar mengenai yang di bahas. Setelah pengenalan topik guru membagi siswa secara berpasangpasangan.Setelah berpasangan guru menyebarkan materi ketiap-tiap siswa dan meminta untuk membaca dan membuat rangkuman.Selain itu guru memutuskan siapa yang menjadi pembicara dan siapa yang menjadi pendengar. Dan guru membuat soal evaluasi yang akan diberikan diakhir proses pembelajaran dan guru bertanya apa yang belum dipahami siswa seputar materi yang dibahas. Pada kegiatan penutup guru bersama siswa membuat kesimpulan lalu dilanjutkan dengan menutup pembelajaran.

b. Tindakan

Melakuakan skenario yang telah dibuat pada RPP dengan menggunakan langkah-langkah dengan apa yang sudah direncanakan sebelumnya. Yaitu sebelum pelajaran dimulai, guru mengajak siswa untuk berdoa bersama-sama, kemudian guru mengenalkan topik yang akan dibahas mengeni konsep bangga sebagai anak Indonesia, membagi siswa untuk berpasangan, Guru menyebarkan bahan materi kepada masing-masing siswa untuk dibaca dan membuat rangkuman setelah itu memutuskan siapa yang menjadi pembicara dan siapa yang berperan sebagai pendengar setelah itu memberikan soal evaluasi individu yang dilakukan untuk mengetahui tingkat keberhasilan hasil belajar siswa. Guru berdialog dengan siswa seputar materi mungkin ada yang belum paham tentang materi yang pelajari .Guru bersama siswa membuat kesimpulan. 
c. Observasi

Dalam kegiatan observasi ini dilakukan saat proses pembelajaran berlangsung. Presentase aktivitas yang diperoleh mencapai $87 \%$ mengalami peningkatan terlihat dari aktivitas siswa dalam maju kedepan kelas untuk mempresentasikan apa yang mereka ringkas dan hapal. presentase 97,1\% dari KKM yang ditentukan sekolah yaitu 63. Dari hasil diatas dapat disimpulkan pada pembelajaran yang dilakukan pada siklus II bahwa kemampuan siswa dalam menguasai materi sudah sangat baik terlihat hanya 1 orang yang belum tuntas.

d. Refleksi

Berdasarkan hasil siklus II kelemahan pada pembelajaran PKn tentang materi bangga sebagai anak Indonesia sudah berkurang dan sudah sangat mencapai hasil yang diharapkan.Hal ini terlihat dari aktivitas dan hasil belajar siswa. Siswa yang belum tuntas hanya $2,9 \%$. Hal ini menunjukkan bahwa adanya peningkatan dari siklus sebelumnya dengan diterapkan model cooperative script.Pertimbangan data yang mengalami perubahan pada proses belajar mengajar dan hasil belajar siswa ditentukan berdasarkan kriteria ketuntasan hasil belajar yakni $80 \%$ untuk mengakhiri penelitian terhadap pembelajaran PKn tentang bangga sebagai anak Indonesia yang dilaksanakan hanya pada Siklus II.

\section{PEMBAHASAN}

Pembahasan Pra Siklus

Kegiatan pra siklus dilakukan pada tanggal 14 maret 2017 di SDIT Harapan Ummat Kecamatan Matraman Jakarta Timur.Mula-mula pada awal pembelajaran guru mengadakan apersepsi dengan mengaitkan materi yang akan disampaikan tetapi saat dalam kegiatan inti guru langsung menuliskan materi dipapan tulis dan setelah itu guru langsung menyampaikan materi dengan metode ceramah sehingga aktivitas siswa kurang aktif. Selain itu banyak siswa menggangu proses pembelajaran dengan mengobrol dan ribut dengan teman sebangkunya.

Nilai rata-rata yang diperoleh pada pra siklus yaitu 36 hasil belajar siswa yang masih sangat kurang, hal ini menandakan bahwa proses belajar mengajar PKn pada konsep bangga sebagai anak Indonesia anak masih kurang memahami sehingga hasil belajar rendah. 


\section{Pembahasan Siklus I}

a. Aktivitas belajar Siswa

Berdasarkan hasil pengamatan pada lembar observasi siswa pada siklus I selama proses pembelajaran PKn pada konsep bangga sebagai anak Indonesia dengan menggunakan model cooperative script menandakan bahwa hasil yang didapat belum memenuhi target. Terlihat dari hasil pengamatan yang dilakukan oleh peneliti nilai yang diperoleh adalah 243 dengan nilai rata-rata 6,9 dipresentasekan menjadi 58\% niali ini menandakan kriteria cukup cuma masih belum memenuhi target yakni 80\%. Maka dapat disimpulkan bahwa nilai yang didapat pada siklus 1 belum mencapai tujuan yang diharapkan.

b. Hasil belajar siswa

Hasil belajar siswa yang diperoleh pada siklus I belum maksimal karena dilihat pada presentase kelulusan hanya 68,6\% nilai tersebut masih kurang karena kriteria ketuntasan belajar yakni $80 \%$ walaupun nilai rata-rata sudah cukup baik yaitu 74. Oleh karena itu peneliti berupaya mencari solusi untuk memperbaiki pembelajaran dengan memperbaiki rencana pelaksanaan pembelajaran dan memperdalami lagi model cooperative script.

\section{Pembahasan Siklus II}

a. Aktivitas belajar Siswa

Berdasarkan hasil pengamatan pada lembar observasi siswa pada siklus II selama proses pembelajaran PKn pada konsep bangga sebagai anak Indonesia dengan menggunakan model cooperative script menandakan bahwa hasil sudah maksimal. Ini terlihat dari hasil pengamatan yang dilakukan oleh peneliti dengan jumlah nilai yang diperoleh sebanyak 367 dengan nilai rata-rata 10,5 dipresentasekan 87\% nilai ini menunjukkan kriteria amat baik. Maka dapat disimpulkan bahwa nilai yang didapat pada siklus II sudah mencapai target yakni $>80 \%$ atau berhasil.

\section{b. Hasil belajar Siswa}

Hasil belajar siswa yang diperoleh pada siklus II sudah baik. Karena dilihat dari presentase kelulusan sudah 97,1\% dan nilai rata-rata mencapai 91,7 dari kriteria ketuntasan hasil belajar 80\% dan KKM yang ditentukan 63. Berdasarkan hasil yang diperoleh pada pra siklus sampai siklus II Adanya peningkatan aktivitas dan hasil belajar sesuai pendapat dari Lambiotte 
menyatakan bahwa cooperative script dimana siswa dalam pembelajaran diminta untuk berpasangan dalam menghapal materi yang telah diringkas. ${ }^{4}$

\section{Penerapan Model Cooperative Script dalam Pembelajaran PKn untuk Meningkatkan Hasil Belajar Siswa pada Konsep Bangga Sebagai Anak Indonesia.}

Berdasarkan analisis hasil penelitian, bahwa terdapat peningkatan terhadap hasil belajar siswa pada pembelajaran PKn dikelas III SD N Kamalaka Kecamtan Taktakan Kota Serang dengan demikian hipotesis tindakan dapat diterima. Adapun gambaran dari rekapitulasi peningkatan aktivitas siswa dan juga hasil belajarnya sebagai berikut :

Tabel 1.

Rekapitulasi Hasil Aktivitas Belajar Siswa

Dengan Menggunakan Cooperative Script

\begin{tabular}{cccccc}
\hline No & Hasil & \multicolumn{3}{c}{ Perolehan Skor } & Keterangan \\
\cline { 3 - 5 } & Observasi & Skor & $\begin{array}{c}\text { Rata- } \\
\text { rata }\end{array}$ & Presentase & \\
\hline 1 & Siklus I & 243 & 6,9 & $58 \%$ & Cukup \\
\hline 2 & Siklus II & 367 & 10,5 & $87 \%$ & Amat Baik \\
\hline
\end{tabular}

Berdasarkan tabel diatas adalah hasil penelitian dalam meningkatkan aktivitas belajar siswa menggunkan model cooperative script ditinjau dari nilai aktivitas belajar siswa pada siklus I jumlah yang diperoleh 243 dengan nilai ratarata 6,9 dipresentasekan menjadi 58\% dalam kriteria penilaian nilai ini termasuk kategori Cukup. Siklus II jumlah nilai yang diperoleh 367 dengan nilai rata-rata 10,5 dipresentasekan menjadi 87\% dalam kriteria penilaian ini termasuk kategori amat baik. Adapun gambaran peningkatan hasil belajar siswa dari pra siklus, siklus I dan II sebagai berikut :

Grafik 1

Rekapitulasi Hasil belajar Siswa

${ }^{4}$ M. Huda, Model-Model Pengajaran..., 213. 
158 | AR-RIAYAH : Jurnal Pendidikan Dasar vol. 2, no. 2, 2018

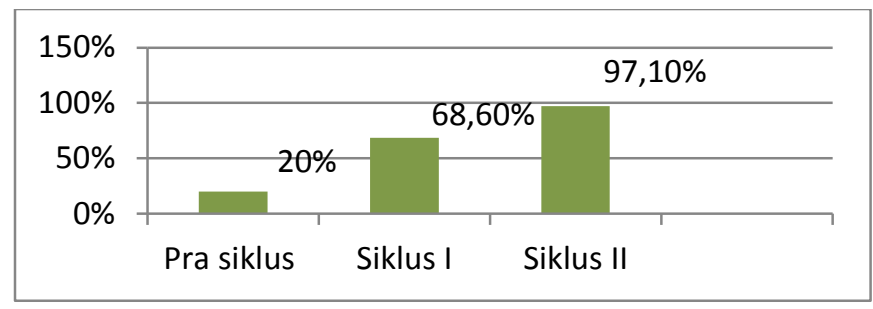

Berdasarkan grafik diatas adanya peningkatan hasil belajar dari tiap siklusnya, dilihat dari awal pra siklus presentase kelulusan 20\%. Siklus I 68,6\% dan Siklus II 97,1\% dengan kriteria ketuntasan siklus yakni 80\%.

\section{KESIMPULAN}

Berdasarkan pelaksanaan dan Hasil penelitian tindakan kelas yang telah dilakukan ini, dapat disimpulkan langkah-langkah pembelajaran PKn dengan menggunakan model cooperative script adalah yang pertama pada awal pembelajaran guru akan memberikan topik mengenai materi yang akan dibahas yakni bangga sebagai anak Indonesia. Setelah pengenalan topik guru membagi siswa berpasang-pasangan dan membuat soal evaluasi untuk diberikan diakhir proses pembelajaran. Dan hasil belajar siswa mengalami peningkatan dari setiap siklusnya hal ini dapat dilihat dari nilai rata-rata pada pra siklus hanya mencapai 36, siklus I mencapai 75,2 dan siklus II mencapai 92. Hal ini menunjukkan bahwa hasil belajar siswa telah mencapai indikator keberhasilan. . Untuk guru sekolah dasar sebaiknya sebagai acuan untuk menyusun RPP dalam rangka meningkatkan kemampuan profesional dalam mengajarkan materi PKn bagi siswa di kelasnya, serta memperluas wawasan dan pengetahuan guru dalam menerapkan model pembelajaran cooperative Script.

\section{DAFTAR PUSTAKA}

Susanto, A. 2012.Teori Belajar dan Pembelajaran.Yogyakarta : Prenada Media Group.

Arikunto. 2013. Prosedur Penelitian Suatu Pendekatan Praktik.Jakarta : Rineka Cipta.

Huda, M. 2013. Model-Model Pengajaran dan Pembelajaran.Yogyakarta : Pustaka Pelajar.

Sugiyono. 2014. Metode Penelitian Kombinasi (Mixed Methods).Bandung : ALFABETA. 